\title{
Druhé ohlédnutí ke Kantovi ${ }^{1}$
}

\author{
Milan Jankovič
}

\begin{abstract}
Looking back at Kant once more

The author of the article deals with Kant's aesthetics, especially with his „Analytic of the Sublime“ from The Critique of Judgment, thus making a connection with his previous „Looking back at Kant", originally published in 1969. Kant's analytic of the sublime is contextualized through the philosophical thinking of Jean-François Lyotard, Paul Ricoeur and Jan Patočka.
\end{abstract}

\section{KEYWORDS}

Aesthetics, analytic of the sublime, Immanuel Kant, Jean-François Lyotard, Paul Ricoeur, Jan Patočka.

\section{KLÍčovÁ SLOVA}

Estetika, analytika vznešeného, Immanuel Kant, Jean-François Lyotard, Paul Ricoeur, Jan Patočka.

Jsou situace, ve kterých už bez potíží nevystačíme s „bezzájmovou libostí“ jako s ústředním pojmem estetiky Immanuela Kanta. Přesněji řečeno vystačíme s ní především v první knize prvního dílu Kritiky soudnosti (Kritik der Urteilskraft,1790), která nese název Analytika krásného. Už druhá kniha prvního dílu nás orientuje jinam, k Analytice vznešeného. Také „vznešené“, jak je pojal Kant, je ovšem záležitostí estetickou, patři do společné oblasti s „krásným“, vzbuzuje jisté estetické city, a je tedy podobně jako krásné pojmenováním subjektivního, ale obecně sdělitelného vkusového soudu. Co je jiné? Úběžník přemýšlení o takovém soudu. Neměla-li hra obrazotvornosti a rozvažování zůstat pouhým potěšením nebo čistou hrou poznávacích schopností, musela do ní vstoupit

1) První „Ohlédnutí ke Kantovi“ vyšlo v Orientaci 4, 1969, č. 1, s. 72-78. Též in: M. Jankovič: Cesty za smyslem literárního díla, Karolinum, Praha 2005, s. 37-50. 
konfrontace s tím, co její autonomii překračuje: to nadměrně velké a hrozné, beztvaré a ničivé. Vůči tomu všemu může být podržena bezzájmová libost jen ve spojení s probuzením citů právě opačných, těch, které provázejí odhodlání hrozivým silám čelit.

Kant rozpracoval podrobné charakteristiky dvou možných způsobů uplatnění vznešeného. Definoval jeho „matematickou“ a „dynamickou“ variantu a postihl při tom základní rysy, jimiž se estetický soud o vznešeném podstatně odlišuje od posouzení krásného. Především není tento soud ani tak výpovědí o předmětu jako spíše o určitém postoji k němu. Vznešený je cit toho, kdo si uchovává ve střetnutí s nepř́iznivými okolnostmi a silami svou lidskou důstojnost a víru ve vlastní rozum. V posouzení vznešeného nezáleží rovněž na formální účelnosti posuzovaného předmětu; cit vznešenosti se poměřuje právě s tím neúčelným, drtivě velkým nebo chaotickým, beztvarým. Bezzájmová libost, která může i v těchto případech provázet pocit překonávání překážek, bývá v té či oné míře smíšená s nelibostí vyvolanou samotnou povahou působícího předmětu. Kant proto upřesňuje a mluví o „negativní libosti“. O nosnosti takového označení nás může přesvědčit následující odbočka.

Pojem „vznešeného“ a smysl návratu k němu ve stati francouzského filozofa Jeana-Françoise Lyotarda má složitější motivaci. Není prostým převzetím někdejších významů spojených s tímto pojmem, nýbrž jejich aktualizací v určité, totiž postmoderní kulturní situaci. ${ }^{2}$ Cit vznešenosti je podle Lyotarda (a ve shodě s ním i podle Kanta) ambivalentní, přináší slast i strast, nebo ještě výrazněji: slast ze strasti samé. „Vynořuje se, když představivost selhává a není s to prezentovat objekt, který by se [...] shodoval s pojmem. Máme Ideu světa (totality toho, co je), ale nemáme schopnost předvést nějaký její příklad. [...] Jsme schopni vytvářet si pojem toho, co je absolutně velké nebo absolutně mocné, ale jakákoli prezentace nějakého objektu, která by nám měla ,ukázat' tuto absolutní velikost nebo absolutní moc, se nám jeví jako bolestně nedostatečná. Toto jsou Ideje, pro něž neexistuje možná prezentace, nedávají tedy poznat žádnou realitu (zkušenost), nepřipouštějí ani svobodnou shodu schopností, která dává vzniknout pocitu krásna, znemožňují vytváření a ustálení vkusu. Lze o nich říci, že jsou nereprezentovatelné, nepředstavitelné“ (LYOTARD 1993: 24). A právě o toto nereprezentovatelné běží podle Lyotarda v moderném malířství. V tomto směru jsou interpretovány rovněž Kantovy výroky o beztvarém, o nepřítomnosti tvaru, charakterizující vnitřně rozpornou povahu libosti ze vznešeného.

2) Stat’ „Vznešené a avantgarda“ pochází z roku 1988; v českém překladu byla využita nejprve v knize Jean-François Lyotard: O postmodernismu, s. 23-28, přel. J. Pechar, Praha 1993; odtud citujeme. 
Ve vyhrocené formulaci pak třeba čteme takový výměr estetiky vznešeného malířství: „[...] jakožto obraz bude samozřejmě něco ,prezentovat', ale negativně, bude se tedy vyhýbat figuraci či zpodobování, bude ,bílé jako nějaký Malevičův čtverec, bude ukazovat jen tím, že nedovolí vidět, bude přinášet slast jen tím, že vyvolá nepříjemný pocit“ (LYOTARD 1993: 25). Malířské avantgardy se podle Lyotarda zaměřily na to, „aby viditelnými prezentacemi dělaly narážku na to, co je nereprezentovatelné“ (IBID.). Kantova estetika zde prokázala překvapivě svou životnost.

Ještě v analytice „vznešeného“ se dostává v Kantově výkladu ke slovu další velké téma Kritiky soudnosti: vlastní moc umělecké tvorby. V ní může hra obrazotvornosti a rozumu pokračovat na jiné úrovni, než jí byla přisouzena v hravém krásnu arabesek: v rozpoutání sil „estetických idejí“, produktů vyšší schopnosti rozumu (Vernunft), jež mohou v souhře s objevnou obrazotvorností naléhat nepředvídatelně na pojmové myšlení a překračovat je. Pohybovat se na této hranici je podle Kanta dáno právě geniálnímu umělci. Aniž je to přímo Kantem takto vysloveno, máme právo se domnívat, že právě v kapitolách věnovaných umění, zejména v paragrafu 49 , byla domyšlena nejurčitěji představa té mohutnosti mysli, která vtiskuje hře obrazotvornosti a rozumu tvořivý vzmach. Propůjčuje jí totiž schopnost „myslet přitom více, i když nerozvinutým způsobem, než se dá vyjádřit v nějakém pojmu, tedy v určitém jazykovém výrazu“ (KANT 1975: 131).

Je příznačné, že se ke Kantovým myšlenkám v uvedeném paragrafu přihlásil hermeneuticky orientovaný francouzský filozof Paul Ricoeur, který navázal v knize La métaphore vive (1975) přímo a výslovně na Kantův „oživující princip v mysli“ (das belebende Prinzip im Gemüte). V zápasu o řečené „myslet více“ pod návodem tohoto principu spatřoval Ricoeur „duši“ interpretace. Měl př́itom na mysli smíšený diskurs (metaforický a spekulativní zároveň), v němž se pojí jasnost pojmu s dynamikou významu. Taková situace nastává podle jeho názoru v Živé metafoře i v Kantově paragrafu 49. V obou případech vznáší tvořivá obrazotvornost vi̊či pojmovému myšlení svůj nesmlouvavý nárok. O tom pojednává Ricoeur šíře v závěru druhé části šesté studie Živé metafory (v jejím německém vydání z roku 1986, které jsem měl k dispozici, pod názvem „Die Überschneidung der Diskurssphären“- Zkřižení diskursivních sfér - na s. 284-285). $\mathrm{V}$ rozvedenější podobě cituje Ricoeur Kantův výklad v odstavci uvedeném pod čarou. V českém vydání Kritiky soudnosti se citovaný odstavec vrací do hlavního textu: „Jestliže nyní nějakému pojmu podřizujeme představu obrazotvornosti, která patří k jeho znázornění, ale pro sebe samotnou dává podnět k tolikerému myšlení, že se v určitém pojmu nikdy nedá shromáždit, tedy esteticky rozšiřuje 
pojem sám neomezeným způsobem; pak je při tom obrazotvornost tvořivá a uvádí do pohybu schopnost intelektuálních idejí (rozum), myslet totiž při podnětu nějaké představy více (což sice k pojmu předmětu patří), než v ní může být pochopeno a učiněno zřetelným“ (KANT 1975: 130).

V „Ohlédnutí ke Kantovi“, uveřejněném na konci šedesátých let, bylo pro mne nejdůležitější rehabilitovat samu „bezzájmovou libost“, v dobovém kontextu u nás (po vydatných ideologických nájezdech z padesátých let) stále ještě nedoceněnou. To se mi snad zčásti podařilo, ale Kantovo druhé velké téma, Analytika vznešeného, zůstalo přitom ve stínu, i když jsem na leckteré jeho motivy upozornil. Nezískaly v mém výkladu svou oprávněnou samostatnost. Tak zůstal nedoceněn už sám obrat Kantův k životně důsažným a svým způsobem vznešeným, totiž hranice empirické zkušenosti přesahujícím „estetickým idejím“, zaznamenaný jen letmo ( $\mathrm{v}$ mé knize Cesty za smyslem literárního díla na s. 44) v německém citátu uvedeném pod čarou: „Básník se odvažuje znázorňovat rozumové ideje neviditelných bytostí, říši blažených, peklo, věčnost, stvoření ap., nebo také to, co sice má příklady ve zkušenosti, např. smrt, závist a všechny neřesti, rovněž lásku, slávu ap., ale co překračuje hranice zkušenosti, smyslově představit prostřednictvím obrazotvornosti, která se snaží následovat rozumovou předehru v dosažení nejvyššího, v úplnosti, pro kterou v př́írodě příklad nenalezneme; a je to vlastně básnictví, ve kterém se může schopnost estetických idejí ukázat v celé své míře" (KANT 1975: 130).

Už z této ukázky je zjevné, jak se proměnilo jeviště, na němž se ted' hra obrazotvornosti a rozumu odehrává. Je to jen zčásti jeviště životní zkušenosti, ukazuje se na něm i to, co empirickou zkušenost daleko přesahuje, a přece na toto jeviště vstupuje jako živě znázorněná estetická, nikoliv tedy jen rozumová idea. Vyšší schopnost rozumu (Vernunft) může dokonce ve svobodné hře s obrazotvorností „vyjádřit a učinit obecně sdělitelným to, co je ve stavu mysli nadsmyslové, at už je výraz jazykem, nebo malírstvím, nebo plastikou [...]“ (KANT 1975: 132). Smyslová konkrétnost estetických idejí není přitom sama o sobě činitelem rozhodujícím. Stává se závažnou teprve ve spojení s rozehranou rozmanitostí částečných představ (atributů), přesahující každý určitý pojem. Teprve ta „dovoluje přimýšlet k pojmu mnoho nepojmenovatelného, jehož pocit oživuje poznávací schopnost, a s jazykem, jako pouhou literou, spojuje ducha“ (KANT 1975: 131). - Představa oživení poznávacích schopností se vrací jako hlubší základ vkusového soudu i zde, v oblasti estetických idejí, v níž se sama bezzájmová libost a účelnost bez účelu zkomplikovaly přechodem od krásného ke vznešenému a zejména - od elementárních otázek estetična $k$ tvořivé moci umění. 
V Negativním platonismu Jana Patočky můžeme číst o možné roli idejí jakožto apelu transcendence. Také v tomto směru se ukazuje životnost Kantovy estetiky, její spřízněnost s novodobým filozofickým myšlením: „Idea, jak my ji chápeme, je jediná non-realita, která nemůže být výkladově osvětlena jako konstrukce z pouhých realit; není předmětem kontemplace, poněvadž není vưbec předmětem; je nezbytná k pochopení lidského života, jeho zkušenosti o svobodě, jeho vnitřní historičnosti; ukazuje se a osvědčuje se jako stálý apel k překročení pouhé dané předmětnosti a věcnosti, jehož vnějším překladem je lidská tvorba nového a stále opakované úsilí vybřednout $\mathrm{z}$ úpadku, $\mathrm{k}$ němuž nás odsuzuje setkávání v pouze daném“" (PATOČKA 1990: 56-57). - Také Kantovy Ideje se vzpínají $\mathrm{k}$ dosažení toho nejvyššího. K nekonečnu? To také, ale především k postižení nadsmyslového základu lidství v nás.

\section{PRAMENY}

KANT, Immanuel

1975 Kritika soudnosti, přel. V. Špalek (Praha: Odeon)

\section{LITERATURA}

JANKOVIČ, Milan

1969 „Ohlédnutí ke Kantovi“, Orientace 4, č. 1, s. 72-78

2005 Cesty za smyslem literárního díla (Praha: Karolinum)

LYOTARD, Jean-François

1993 O postmodernismu, přel. J. Pechar (Praha: Filosofický ústav AV ČR)

RICOEUR, Paul

1975 La métaphore vive (Paris: Editions du Seuil)

1986 Die lebendige Metapher; übersetzt von R. Rochlitz (München: W. Fink Verlag)

PATOČKA, Jan

1990 Negativní platonismus (Praha: Československý spisovatel)

PhDr. Milan Jankovič,DrSc., mjankovic@centrum.cz, Ústav pro českou literaturu AV $\check{C} R$, Česká republika / Institut of Czech literature AS CR, Czech Republic 